\title{
PENGARUH LINGKUNGAN KERJA TERHADAP KINERJA KARYAWAN CV. PERKASA MOTOR DI KOTA JAYAPURA
}

\author{
Heber Moyau*, Munawir Lobubun** dan Fitriani** \\ *Mahasiswa Prodi Manajamen, Sekolah Tinggi Ilmu Ekonomi Port Numbay \\ **Dosen Prodi Manajemen, Sekolah Tinggi Ilmu Ekonomi Port Numbay
}

\begin{abstract}
The purpose of this study was to determine and analyze the effect of the work environment on the performance of employees of CV. Perkasa Motor in Jayapura City. This research is a quantitative research using simple linear regression statistical analysis method. Data analysis in this study used descriptive analysis and simple linear regression analysis ( $t$ test, correlation coefficient and coefficient of determination) assisted by the SPSS 22 for windows program. Based on descriptive analysis shows that the majority of respondents agree with the work environment in CV. Perkasa Motor is good so that performance increases, while the statistical tests that have been described can be seen that the work environment variable affects employee performance variables and it can be seen that the work environment affects employee performance CV. Perkasa Motor in Jayapura City, so that the first hypothesis that the work environment has a positive and significant effect is accepted, while the second hypothesis states that the work environment has no effect on employee performance which is rejected, meaning that the work environment has a positive and significant effect on employee performance CV. Perkasa Motor in Jayapura City. In addition, the coefficient of determination shows that there is an influence of the work environment on the performance of CV employees. Perkasa Motor in Jayapura City by 53.9\%, while the rest is influenced by other variables or factors not examined.
\end{abstract}

Keywords: Work Environment, Employee Performance

\begin{abstract}
Abstrak: Tujuan dari penelitian ini adalah untuk mengetahui dan menganalisis pengaruh lingkungan kerja terhadap kinerja karyawan CV Perkasa Motor di Kota Jayapura. Penelitian ini adalah penelitian kuantitatif dengan menggunakan metode analisis statistik regresi linier sederhana. Analisis data dalam penelitian ini menggunakan analisis deskriptif dan analisis regresi linear sederhana (uji t, koefisien korelasi dan koefisien determinasi) yang dibantu dengan program SPSS 22 for windows. Berdasarkan hasil analisis deskriptif menunjukkan bahwa mayoritas responden menyetujui lingkungan kerja yang ada di CV. Perkasa Motor sudah baik sehingga kinerja karyawan meningkat, sedangkan pengujian statistik yang telah peneliti paparkan dapat terlihat bahwa variabel lingkungan kerja berpengaruh terhadap variabel kinerja karyawan dan dapat di lihat lingkungan kerja berpengaruh terhadap kinerja karyawan CV. Perkasa Motor di Kota Jayapura, sehingga hipotesis pertama yang menyatakan diduga lingkungan kerja berpengaruh positif dan signifikan yang diterima, sedangkan hipotesis kedua yang menyatakan lingkungan kerja tidak berpengaruh terhadap kinerja karyawan yang ditolak, artinya lingkungan kerja berpengaruh secara positif dan signifikan terhadap kinerja karyawan CV. Perkasa Motor di Kota Jayapura. Selain itu, nilai koefisien determinasi menunjukkan bahwa terdapat pengaruh lingkungan kerja terhadap kinerja karyawan CV. Perkasa Motor di Kota Jayapura sebesar 53,9\%, sedangkan sisanya dipengaruhi oleh variabel atau faktor lain yang tidak diteliti.
\end{abstract}

Kata Kunci : Lingkungan Kerja, Kinerja Karyawan

\section{Pendahuluan}

Berbagai isu mengenai karyawan layak mendapatkan perhatian bagi perusahaan karena karyawan merupakan sumber daya penting bagi kesuksesan perusahaan. Menurut Mensah dan Tawiah (2016) kunci keberhasilan atau kegagalan perusahaan sangat ditentukan oleh karyawan perusahaan. Karyawan yang memiliki kemampuan atau kompetensi tinggi dalam bekerja mampu memberikan kinerja yang tinggi bagi perusahaan, sehingga ketika karyawan tersebut keluar dari perusahaan berarti perusahaan telah mengalami kerugian.

Perusahaan memiliki sejumlah tujuan-tujuan yang harus dicapai dalam pelaksanaan operasionalnya. Penetapan tujuan-tujuan tersebut didasarkan pada kemampuan sumberdaya yang dimiliki khususnya sumberdaya manusia. Menurut Dobre (2013), untuk mencapai tujuan, maka perusahaan perlu membangun
On Assets.

strategi untuk bisa bersaing dalam pasar yang kompetitif dan dengan meningkatkan kinerja perusahaan. Dalam fenomena persaingan yang semakin ketat antar perusahaan, setiap perusahaan berusaha untuk bisa tampil lebih baik dibandingkan pesaing. Keunggulan kompetitif tersebut baru bisa dicapai ketika perusahaan memiliki kinerja yang tinggi. Kinerja perusahaan tergantung pada kinerja karyawan karena karyawan yang merencanakan, melaksanakan, dan yang melakukan evaluasi atas kinerja operasional. Menurut Siagian (2002), kinerja karyawan dipengaruhi oleh beberapa faktor yaitu : gaji, lingkungan kerja, budaya organisasi, kepemimpinan dan motivasi kerja, disiplin kerja, kepuasan kerja, komunikasi dan faktor-faktor lainnya.

Dari beberapa faktor diatas, untuk meningkatkan kinerja karyawan salah satunya adalah dengan 
memperhatikan faktor lingkungan kerja. Kondisi lingkungan kerja yang tidak sehat dapat menyebabkan para karyawan mudah stres, tidak semangat untuk bekerja, datang terlambat, demikian juga sebaliknya apabila lingkungan kerja itu sehat maka para karyawan tentunya akan semangat dalam bekerja, tidak mudah sakit, mudah untuk konsentrasi sehingga pekerjaan menjadi cepat selesai sesuai dengan target. Lingkungan kerja sendiri mempunyai dua dimensi, yaitu dimensi fisik (pewarnaan ruangan, pencahayaan, kebersihan, tata ruang) dan dimensi non fisik (kesejahteraan karyawan, suasana kerja, hubungan antar karyawan). Perusahaan harus mampu menyediakan kedua dimensi tersebut dalam keadaan baik sehingga mampu membuat para karyawan untuk tetap bekerja dengan produktif dan saling bekerja sama antar karyawan maupun dengan pimpinan untuk mencapai tujuan organisasi.

Lingkungan kerja adalah segala sesuatu yang ada disekitar para pekerja yang dapat mempengaruhi dirinya dalam menjalankan tugas-tugas yang dibebankan. Misalnya kebersihan, musik dan lain-lain, (Nitisemito, 2001). Menurut Sedarmayati (2011) Lingkungan kerja maksudnya adalah keseluruhan alat perkakas dan bahan yang dihadapi, lingkungan sekitarnya di mana seseorang bekerja, metode kerjanya, serta pengaturan kerjanya baik sebagai perseorangan maupun sebagai kelompok. Sedangkan Mardiana (2001) menjelaskan bahwa Lingkungan kerja adalah lingkungan dimana pegawai melakukan pekerjaannya sehari-hari.

CV. Perkasa Motor merupakan perusahaan yang bergerak dibidang penjualan barang sparepart kendaraan bermotor dan tentunya bertujuan untuk meningkatkan profit perusahaan. Untuk mewujudkan hal tersebut maka sudah tentu seluruh karyawannya diharapkan untuk dapat melakukan pelayanan dengan sebaik-baiknya disemua aspek, serta dapat bekerja sesuai harapan yang diinginkan. Faktor yang berpengaruh langsung dengan kinerja pegawai adalah lingkungan kerja, karena dengan lingkungan kerja yang baik dan nyaman dapat mempermudah pegawai dalam menjalankan pekerjaanya dan akan memotivasi karyawannya untuk bekerja lebih giat sehingga meningkatkan kinerja mereka, oleh sebab itu perusahaan harus memperhatikan lingkungan kerja dimana pegawai bekerja, untuk meningkatkan kinerja pegawai.

Ditinjau dari sisi lingkungan kerja, maka Lingkungan kerja karyawan CV. Perkasa Motor di Kota Jayapura masih perlu dibenahi salah satunya banjir ketika hujan deras, hal ini dapat menghambat karyawan dalam melakukan pekerjaannya, sehingga membuat kinerjanya menurun. Selain itu adanya fluktuatif kinerja karyawan yaitu kemangkiran karyawan, kinerja karyawan menurun dan beberapa karyawan datang tidak tepat waktu, serta penyelesaian pekerjaan tidak sesuai yang diharapkan yang disebabkan dari lingkungan kerjanya, Ada sebagian karyawan yang merasa di lingkungan kerja mereka tidak nyaman dengan situasi dan kondisi di lingkungan kerja sehingga menyebabkan kinerja karyawan tersebut turun. Ada pada saatnya karyawan tersebut nyaman dengan lingkungan kerja sehingga kinerja karyawan tersebut meningkat.

\section{Tujuan Penelitian}

Adapun tujuan penelitian berdasarkan rumusan masalah di atas, maka tujuan dari penelitian ini yaitu untuk mengetahui dan menganalisis pengaruh lingkungan kerja terhadap kinerja karyawan CV. Perkasa Motor di Kota Jayapura.

\section{Kajian Teori \\ Lingkungan Kerja}

Lingkungan kerja dalam suatu perusahaan perlu diperhatikan, hal ini disebabkan karena lingkungan kerja mempunyai pengaruh langsung terhadap para karyawan. Lingkungan kerja yang kondusif dapat meningkatkan kinerja karyawan dan sebaliknya, lingkungan kerja yang tidak memadai akan dapat menurunkan kinerja karyawan. Kondisi lingkungan kerja dikatakan baik apabila manusia dapat melaksanakan kegiatan secara optimal, sehat, aman dan nyaman. Kesesuaian lingkungan kerja dapat dilihat akibatnya dalam jangka waktu yang lama. Lingkungan kerja yang kurang baik dapat menuntut tenaga kerja dan waktu yang lebih banyak dan tidak mendukung diperolehnya rancangan sistem kerja yang efisien. Menurut Robbins (2010) lingkungan adalah lembaga-lembaga atau kekuatan-kekuatan diluar yang berpotensi mempengaruhi kinerja organisasi, lingkungan dirumuskan menjadi dua yaitu lingkungan umum dan lingkungan khusus. Lingkungan umum adalah segala sesuatu di luar organisasi yang memilki potensi untuk mempengaruhi organisasi. Lingkungan ini berupa kondisi sosial dan teknologi. Sedangkan lingkungan khusus adalah bagian lingkungan yang secara langsung berkaitan dengan pencapaian sasaransasaran sebuah organisasi. Sofyandi (2008) mendefinisikan "Lingkungan kerja sebagai serangkaian faktor yang mempengaruhi kinerja dari fungsi-fungsi/aktivitas-aktivitas manajemen sumber daya manusia yang terdiri dari faktorfaktor internal yang bersumber dari dalam organisasi".

\section{Faktor-Faktor Lingkungan Kerja}

Menurut Siagian (2006) untuk menciptakan lingkungan kerja yang baik ada beberapa hal yang harus diperhatikan yaitu :

1. Bangunan tempat kerja

2. Ruang kerja yang lega

3. Ventilasi pertukaran udara

4. Tersedianya tempat-tempat ibadah keagamaan

5. Tersedianya sarana angkutan khusus maupun umum untuk karyawan nyaman dan mudah.

\section{Manfaat Lingkungan Kerja}

Menurut Ishak dan Tanjung (2003) manfaat lingkungan kerja adalah menciptakan gairah kerja, sehingga produktivitas dan prestasi kerja meningkat. Sementara itu, manfaat yang diperoleh karena bekerja dengan orang-orang yang termotivasi adalah pekerjaan dapat diselesaikan dengan tepat yang artinya pekerjaan 
diselesaikan sesuai standard yang benar dan dalam skala waktu yang ditentukan. Prestasi kerjanya akan dipantau oleh individu yang bersangkutan dan tidak akan menimbulkan terlalu banyak pengawasan serta semangat juangnya akan tinggi.

\section{Kinerja}

Kinerja berasal dari pengertian performance. Ada pula yang memberikan pengertian performance sebagai hasil kerja atau prestasi kerja. Namun sebenarnya kinerja mempunyai makna yang luas, bukan hanya hasil kerja, tetapi termasuk bagaimana proses pekerjaan berlangsung (Wibowo, 2007). Lebih lanjut Simamora (2006) menyampaikan bahwa kinerja (performance) mengacu kepada kadar pencapaian tugas-tugas yang membentuk sebuah pekerjaan karyawan dan merefleksikan seberapa baik karyawan memenuhi persyaratan sebuah pekerjaan, namun sering disalah tafsirkan sebagai upaya (effort) yang mencerminkan energi yang dikeluarkan, kinerja diukur dari segi hasil.

Dari beberapa definisi di atas, dapat disimpulkan bahwa kinerja merupakan suatu hasil kerja yang dicapai oleh seseorang dalam melakukan tugas atau pekerjaannya berdasarkan kemampuan kerja baik secara kualitas maupun kuantitas sesuai dengan tanggung jawab yang diberikan kepadanya.

\section{Faktor-faktor yang Mempengaruhi Kinerja Karyawan}

Menurut Mathis dan Jackson (2009) sistem penilaian kinerja seringkali menjadi penghubung antara penghargaan yang diinginkan karyawan dan produktivitas mereka. Kompensasi yang berbasis kinerja menegaskan ide bahwa kenaikan gaji seharusnya diberikan untuk pencapaian kinerja dari pada untuk senioritas. Dalam sistem ini, manajer secara historis telah menjadi pengevaluasi dari kinerja bawahan dan juga yang membuat rekomendasi kompensasi untuk karyawan. Penilaian kinerja dapat menjadi sumber utama informasi dan umpan balik untuk karyawan, yang sering kali merupakan kunci perkembangan mereka di masa depan (Mathis dan Jackson, 2009).

\section{Penilaian Kerja Karyawan}

Penilaian kinerja dikenal dengan istilah "performance rating" atau "performance appraisal". Menurut Munandar (2008) penilaian kinerja adalah proses penilaian ciri-ciri kepribadian, perilaku kerja, dan hasil kerja seseorang tenaga kerja atau karyawan (pekerja dan manajer), yang dianggap menunjang unjuk kerjanya, yang digunakan sebagai bahan pertimbangan untuk pengambilan keputusan tentang tindakan-tindakan terhadap bidang ketenagakerjaan. Suatu perusahaan melakukan penilaian kinerja didasarkan pertimbangan bahwa perlu adanya suatu sistem evaluasi yang objektif terhadap organisasional. Selain itu, dengan adanya penilaian kinerja manajer puncak dapat memperoleh dasar yang objektif untuk memberikan kompensasi sesuai dengan prestasi yang disumbangkan masing-masing pusat pertanggungjawaban kepada perusahaan secara keseluruhan. Semua ini diharapkan dapat membentuk motivasi dan rangsangan kepada masingmasing bagian untuk bekerja lebih efektif dan efisien.

\section{Manfaat Kinerja}

Menurut Sedarmayanti (2003) terdapat beberapa manfaat dari pada kinerja tersebut, yaitu :

1) Peningkatan prestasi, dengan adanya penilaian baik manajer maupunkaryawan memperoleh umpan balik dan mereka dapat memperbaiki pekerjaan mereka.

2) Kesempatan kerja yang adil, adanya penilaian kinerja yang akurat dapat menjamin karyawan untuk memperoleh kesempatan menempati posisi pekerja sesuai dengan kemampuannya.

3) Kebutuhan Pelatihan dan Pengembangan, melalui penilaian prestasi kerjaakan dideteksi karyawan yang kemampuannya rendah sehingga memungkinkan adanya program pelatihan untuk meningkatkan kemampuan mereka.

4) Penyesuaian Kompensasi, penilaian prestasi kerja dapat membantu para manajer untuk mengambil kepuasan dalam menentukan perbaikan pemberian kompensasi, gaji, insentif dan sebagainya.

5) Keputusan Promosi dan Demosi, hasil penilaian prestasi kerja terhadap karyawan dapat digunakan untuk mengambil keputusan dalam rangka mempromosikan dan mendemosikan karyawan yang prestasi kerjanya kurang baik.

\section{Metode Penelitian \\ Teknik Analisis Data}

Untuk menganalisisi permasalahan yang ada, maka dalam penulisan ini metode analisis data yang digunakan sebagai berikut :

1. Analisis kualitatif yaitu analisis data tidak dapat dinominasikan dengan menggunakan angka melainkan dapat disajikan dalam bentuk keterangan, penjelasan dan pembahasan teori.

2. Analisis kuantitatif yaitu analisis data dalam bentuk angka-angka yang pembahasannya melalui perhitungan statistik berdasarkan jawaban kuesioner dari responden. Kemudian data diolah secara statistik dengan menggunakan alat bantu program SPSS untuk membuktikan hubungan dan pengaruh antar variabelvariabel penelitian dengan menggunakan persamaan regresi linier sederhana dan uji statistik sebagai berikut

a. Uji Validitas

Uji ini dilakukan dengan cara membandingkan angka $r_{\text {hitung }}$ dan $r_{\text {tabel }}$. Jika $r_{\text {hitung }}$ lebih besar dari $r_{\text {tabel}}$, maka item dikatakan valid dan sebaliknya jika $r_{\text {hitung }}$ lebih kecil dari $r_{\text {tabel, }}$ maka item dikatakan tidak valid. $r_{\text {hitung dicari dengan }}$ menggunakan program SPSS, sedangkan $r_{\text {tabel }}$ dicari dengan cara melihat tabel $\mathrm{r}$ minimal adalah 0,3 . (Sugiyono, 2011).

b. Uji Realibilitas

Uji ini dilakukan dengan cara membandingkan angka cronbach alpha dengan ketentuan milai cronbach alpha minimal adalah 0,60 artinya jika nilai cronbach alpha yang didapatkan dari hasil perhitungan SPSS lebih besar dari 0,60, maka disimpulkan kuesioner tersebut reliable, 
sebaliknya jika cronbach alpha lebih kecil dari 0,6 maka disimpulkan reliabel. (Sugiyono, 2011).

c. Analisis Regresi

Untuk mengetahui apakah variabel lingkungan kerja $(\mathrm{X})$ berpengaruh terhadap kinerja karyawan (Y), maka digunakan persamaan regresi sederhana menurut Sugiyono (2016) :

Dimana,

$$
\mathbf{Y}=\mathbf{a}+\mathbf{b x}
$$

$\mathrm{Y}=$ Kinerja Karyawan

$\mathrm{a}=$ Konstanta atau bila $\mathrm{x}=0$

$\mathrm{b}=$ Koefisien Regresi

$\mathrm{x}=$ lingkungan kerja

d. Koefisien Determinasi $\left(\mathrm{R}^{2}\right)$

Koefisien determinasi pada intinya mengukur seberapa jauh kemampuan variabel bebas dalam menerangkan variabel terikat. Nilai koefisien determinasi yang mendekati satu berarti variabelvariabel independennya menjelaskan hampir semua informasi yang dibutuhkan untuk memprediksi variabel dependen (Ghozali, 2009).

e. Uji-t

Uji-t atau dikenal dengan istilah uji parsial adalah pengujian untuk mengetahui pengaruh masing-masing yang terdiri dari variabel lingkungan kerja (X) terhadap kinerja karyawan (Y) dengan cara membandingkan antara $t_{\text {hitung }}>t_{\text {tabel }}$ maka hipotesis diterima. Untuk menentukan formulasi hipotesis sebagai berikut:

Ho:b1 = artinya ada pengaruh dari variabel bebas $(\mathrm{X})$ terhadap variabel terikat $(\mathrm{Y})$.

Ha b1 $\neq 0$ artinya tidak ada pengaruh dari variabel bebas $(\mathrm{X})$ terhadap variabel terikat (Y).

\section{Hasil analisis \\ Persamaan Regresi}

Dengan menggunakan analisis regresi linear sederhana yang diolah dengan menggunakan program SPSS untuk mengetahui berapa besar pengaruh variabel lingkungan kerja (X) terhadap kinerja karyawan (Y) CV. Perkasa Motor di Kota Jayapura, maka dapat dibuat persamaan regresi linear sederhana dari tabel 4.8 seperti berikut ini :

$$
Y=6,528+0,599 X
$$

Dari persamaan regresi linear sederhana menunjukkan bahwa :

a) Nilai konstanta 6,528 yang berarti apabila tidak memperhitungkan adanya variabel lingkungan kerja (X), maka kinerja karyawan (Y) sebesar 6,528 dengan asumsi bahwa variabel lain tetap.

b) Nilai koefisien regresi lingkungan kerja (X) sebesar 0,599 mengandung makna bahwa apabila lingkungan kerja meningkat sebesar satu satuan maka akan meningkatkan kinerja karyawan (Y) sebesar 0,599.

\section{Uji Hipotesis}

Untuk menjawab hipotesa penelitian ini yaitu diduga variabel penilaian lingkungan kerja (X) berpengaruh terhadap kinerja karyawan (Y) CV. Perkasa Motor di Kota Jayapura, akan dijelaskan berdasarkan uji t, persamaan regresi serta koefisien korelasi berikut ini.

\section{a. Uji-t}

Untuk membuktikan apakah variabel lingkungan kerja $(\mathrm{X})$ berpengaruh terhadap kinerja karyawan (Y) CV. Perkasa Motor di Kota Jayapura, maka digunakan uji-t. Berdasarkan hasil analisis dengan menggunakan program SPSS, dapat diketahui hasil uji-t pada tabel 4.8 berikut ini :

Tabel 4.8

\begin{tabular}{|c|c|c|c|c|c|}
\hline \multirow[b]{2}{*}{ Model } & \multicolumn{2}{|c|}{$\begin{array}{c}\text { Unstandardized } \\
\text { Coefficients } \\
\end{array}$} & \multirow{2}{*}{\begin{tabular}{|c|}
$\begin{array}{c}\text { Standardized } \\
\text { Coefficients }\end{array}$ \\
Beta \\
\end{tabular}} & \multirow[b]{2}{*}{$\mathrm{t}$} & \multirow[b]{2}{*}{ Sig. } \\
\hline & $\mathrm{B}$ & Std. Error & & & \\
\hline $\begin{array}{ll}1 & \text { (Constant) } \\
& \text { Lingkungan Kerja }\end{array}$ & $\begin{array}{r}6,528 \\
, 599\end{array}$ & $\begin{array}{r}1,533 \\
, 098\end{array}$ & ,734 & $\begin{array}{l}4,257 \\
6,111\end{array}$ & $\begin{array}{l}, 000 \\
, 000 \\
\end{array}$ \\
\hline
\end{tabular}

Coefficients $^{\mathbf{a}}$

a. Dependent Variable: Kinerja

Berdasarkan hasil tersebut maka hipotesis $\left(\mathrm{H}_{1}\right)$

Sumber : Data diolah, 2020

Dari hasil olah data menggunakan program SPSS dari tabel 4.8 di atas, dapat diketahui nilai $t_{\text {hitung }}$ untuk variabel lingkungan kerja (X) sebesar 6,111 dengan tingkat signifikan $0,000<0,05$, sedangkan nilai $\mathrm{t}_{\text {tabel }}(\mathrm{n}-\mathrm{k})$ atau (34-2) sebesar 1,693. Dengan demikian dapat dikatakan bahwa variabel lingkungan kerja mempunyai pengaruh yang signifikan terhadap kinerja karyawan. dapat diterima, yaitu terdapat pengaruh yang signifikan antara lingkungan kerja (X) terhadap kinerja karyawan (Y) CV. Perkasa Motor di Kota Jayapura.

b. Koefisien Korelasi dan Koefisien Determinasi

Untuk mengetahui adanya pengaruh lingkungan kerja terhadap kinerja karyawan CV. Perkasa Motor di Kota Jayapura, maka digunakan bantuan program SPSS dalam pengolahan data sehingga didapatkan hasil sesuai dengan tabel 4.9 berikut ini : 
Tabel 4.9

Model Summary ${ }^{b}$

\begin{tabular}{|l|r|r|r|c|}
\hline Model & R & R Square & \multicolumn{1}{c|}{$\begin{array}{c}\text { Adjusted R } \\
\text { Square }\end{array}$} & $\begin{array}{c}\text { Std. Error of the } \\
\text { Estimate }\end{array}$ \\
\hline 1 &, $734^{\mathrm{a}}$ &, 539 &, 524 & 1,32400 \\
\hline
\end{tabular}

a. Predictors: (Constant), Lingkungan Kerja

b. Dependent Variable: Kinerja

Sumber : Data diolah, 2020

Berdasarkan hasil analisis pada tabel 4.9 di atas, dapat dilihat bahwa nilai koefisien korelasi (R) sebesar 0,734 yang menunjukkan bahwa variabel lingkungan kerja (X) memiliki hubungan yang kuat terhadap variabel kinerja karyawan (Y) CV. Perkasa Motor di Kota Jayapura. Selain itu, nilai koefisien determinasi $\mathrm{R}^{2}$ sebesar 0,539 yang menunjukkan bahwa terdapat pengaruh lingkungan kerja terhadap kinerja karyawan CV. Perkasa Motor di Kota Jayapura sebesar 0,539 atau $53,9 \%$, sedangkan sisanya 0,461 atau $46,1 \%$ dipengaruhi oleh variabel atau faktor lain yang tidak diteliti.

\section{Pembahasan}

Berdasarkan hasil analisis deskriptif menunjukkan bahwa mayoritas responden menyetujui lingkungan kerja yang ada di CV. Perkasa Motor sudah baik sehingga kinerja karyawan meningkat, sedangkan pengujian statistik yang telah peneliti paparkan dapat terlihat bahwa variabel lingkungan kerja berpengaruh terhadap variabel kinerja karyawan dan dapat dilihat lingkungan kerja berpengaruh terhadap kinerja karyawan CV. Perkasa Motor di Kota Jayapura, hasil penelitian lingkungan kerja terhadap kinerja karyawan dapat dijelaskan berdasarkan hasil uji t variabel lingkungan kerja menghasilkan nilai signifikan 0,000 yang di mana nilai ini lebih kecil dari 0.05 dan hasil t-hitung $(6,111)>$ t-tabel $(1,693)$ sehingga hipotesis pertama yang menyatakan diduga lingkungan kerja berpengaruh positif dan signifikan yang diterima, sedangkan hipotesis kedua yang menyatakan lingkungan kerja tidak berpengaruh terhadap kinerja karyawan yang ditolak, artinya lingkungan kerja berpengaruh secara positif dan signifikan terhadap kinerja karyawan CV. Perkasa Motor di Kota Jayapura, ini berarti lingkungan kerja sangat didukung oleh semua karyawan, karena dengan lingkungan kerja yang baik, maka akan menimbulkan semangat kerja, memberikan motivasi dan kekuatan bagi para karyawan untuk meningkatkan kerjanya, dengan lingkungan kerja yang baik pula akan meningkatkan produktivitas kerja karyawan. Selain itu, nilai koefisien determinasi $\mathrm{R}^{2}$ sebesar 0,539 yang menunjukkan bahwa terdapat pengaruh lingkungan kerja terhadap kinerja karyawan CV. Perkasa Motor di Kota Jayapura sebesar 53,9\%, sedangkan sisanya yaitu sebesar $46,1 \%$ dipengaruhi oleh variabel atau faktor lain yang tidak diteliti.

Lingkungan kerja yang kondusif dapat meningkatkan kinerja karyawan dan sebaliknya, lingkungan kerja yang tidak memadai akan dapat menurunkan kinerja karyawan. Kondisi lingkungan kerja dikatakan baik apabila manusia dapat melaksanakan kegiatan secara optimal, sehat, aman dan nyaman. Kesesuaian lingkungan kerja dapat dilihat akibatnya dalam jangka waktu yang lama. Lingkungan kerja yang kurang baik dapat menuntut tenaga kerja dan waktu yang lebih banyak dan tidak mendukung diperolehnya rancangan sistem kerja yang efisien. Menurut Robbins (2010) lingkungan adalah lembaga-lembaga atau kekuatankekuatan diluar yang berpotensi mempengaruhi kinerja organisasi, lingkungan dirumuskan menjadi dua yaitu lingkungan umum dan lingkungan khusus. Lingkungan umum adalah segala sesuatu di luar organisasi yang memilki potensi untuk mempengaruhi organisasi. Lingkungan ini berupa kondisi sosial dan teknologi. Sedangkan lingkungan khusus adalah bagian lingkungan yang secara langsung berkaitan dengan pencapaian sasaransasaran sebuah organisasi.

\section{Kesimpulan}

Berdasarkan hasil analisis deskriptif menunjukkan bahwa mayoritas responden menyetujui lingkungan kerja yang ada di CV. Perkasa Motor sudah baik sehingga kinerja karyawan meningkat, sedangkan pengujian statistik yang telah peneliti paparkan dapat terlihat bahwa variabel lingkungan kerja berpengaruh terhadap variabel kinerja karyawan dan dapat di lihat lingkungan kerja berpengaruh terhadap kinerja karyawan CV. Perkasa Motor di Kota Jayapura, sehingga hipotesis pertama yang menyatakan diduga lingkungan kerja berpengaruh positif dan signifikan yang diterima, sedangkan hipotesis kedua yang menyatakan lingkungan kerja tidak berpengaruh terhadap kinerja karyawan yang ditolak, artinya lingkungan kerja berpengaruh secara positif dan signifikan terhadap kinerja karyawan CV. Perkasa Motor di Kota Jayapura. Selain itu, nilai koefisien determinasi menunjukkan bahwa terdapat pengaruh lingkungan kerja terhadap kinerja karyawan CV. Perkasa Motor di Kota Jayapura sebesar 53,9\%, sedangkan sisanya yaitu sebesar $46,1 \%$ dipengaruhi oleh variabel atau faktor lain yang tidak diteliti.

\section{Daftar Pustaka}

Arikunto, Suharsimi. (1996). Prosedur Penelitian Suatu Pendekatan Praktik. Edisi Revisi. Jakarta: Rineka Cipta.

Armstrong, M. and Baron, A. 1998. Performance Management -The New Realities. London: Institute of Personnel and Development.

Basuki, dan Susilowati, Indah. 2005. "Dampak Kepemimpinan, dan Lingkungan 
Kerja, Terhadap Semangat Kerja”. Jurnal JRBI. Vol 1 No 1. Hal : 31-47

Cascio, W.F. 1992. Managing Human Resources : Productivity, Quality of Work Life, Profits. Edisi ke-3. Managing Human Resources: Productivity, Quality of Work. Mc Graw-Hill Companies, Inc. USA.

Cooper, Donald R.C. dan Emory, William. 1998. Metode Penelitian Bisnis. Erlangga, Jakarta.

Dobre Ovidiu Iluita. 2013. Employee Motivation and Organizational Performance. Vol. 5 Iss 1, pp. 53. Review of Applied Socio-Economic Research 2247-6172.

Ghozali, Imam. 2009. Aplikasi Analisis Multivariate dengan Program SPSS. Semarang : UNDIP.

Gie, The Liang. 2000. Administrasi Perkantoran Modern. Yogyakarta. Liberty.

Gomes, Faustino Cardoso. 2003. Manajemen Sumber Daya Manusia. Jakarta: Andi Offset.

Hariandja, Marihot Tua Efendi. 2005. Manajemen Sumber Daya Manusia.Jakarta: PT.Grasindo.

Heidjrachman dan Husnan, Suad 1997. Manajemen Personalia (Ed. 4).. Yogyakarta: BPFE.

Iluita, Dobre Ovidiu. 2013. "Employee Motivation and Organizational Performance". Vol. 5 Iss 1, pp. 53. Review of Applied Socio-Economic Research 2247-6172.

Indriantoro, Nur, dan Supomo, Bambang. 1999. Metodologi Penelitian dan Bisnis, Yogyakarta: BPFE Yogyakarta.

Mahsun. 2013. Metode Penelitiam Bahasa: Tahapan, Strategi, Metode, dan Tekniknya. Jakarta: Rajagrafindo Persada.

Mangkunegara, A. A. Anwar Prabu. 2006, Perencanaan dan Pengembangan Manajemen Sumber Daya Manusia, Pen. PT Refika Aditama.

Mangkunegara, A. A. Anwar Prabu. 2010. Manajemen Sumber Daya Manusia Perusahaan. Bandung: PT Remaja Rosdakarya.

Mathis, Robert L dan Jackson, John H. 2009. Manajemen Sumber Daya Manusia: Buku Dua. Salemba Empat: Jakarta.

Mensah, E.B.K. dan Tawiah, K.A. 2016. Employee Motivation and Work Performance : A Comparative Study of Mining Companies in Ghana. Journal of Industrial Engineering and Management 9(2), 255-309.

Munandar, Ashar Sunyoto. 2008. Psikologi Industri dan Organisasi. Penerbit Universitas Indonesia (UI-Press).

Nazir, Moh. 2005. Metode Penelitian. Jakarta: Ghalia Indonesia.

Nitisemito, Alex S. 1992. Manajemen dan Sumber Daya Manusia, BPFE UGM, Yogyakarta.
Nitisemito, Alex S. 2000. Manajemen Personalia: Manajemen Sumber Daya Manusia, Ed. 3, Ghalia Indonesia, Jakarta.

Nitisemito, Alex S. 2001. Manajemen Personalia. Jakarta: Ghalia Indonesia.

Nuraini, T. 2013. Manajemen Sumber Daya Manusia, Yayasan Aini Syam: Pekanbaru.

Oei, Istijanto. 2010. Riset Sumber Daya Manusia. Gramedia Pustaka Utama. Edisi Revisi.

Rivai, Veithzal dan Sagala, Ella Jauvani. 2009. Manajemen Sumber Daya Manusia untuk Perusahaan dari Teori ke Praktik. Jakarta: PT Raja Grafindo.

Robbins, Stephen P. 2006. Perilaku Organisasi. Edisi Sepuluh. Diterjemahkan oleh: Drs. Benyamin Molan. Erlangga, Jakarta.

Sedarmayanti. 2009. Sumber Daya Manusia dan Produktivitas Kerja. Bandung: CV Mandar Maju.

Siagian, Sondang P, 2006. Manajemen Sumber Daya Manusia, Cetakan Ketiga belas, Bumi Aksara, Jakarta.

Simamora, Henry. 2006. Manajemen Sumberdaya Manusia. Yogyakarta: Sekolah Tinggi Ilmu Ekonomi YKPN.

Sugiyono. 2004. Metode Penelitian. Bandung: Alfabeta.

Sugiyono. 2005. Memahami Penelitian Kualitatif. Bandung: CV. Alfabeta.

Sugiyono. 2011. Metode Penelitian Kuantitatif, Kualitatif dan R\&D. Bandung: Afabeta.

Sugiyono. 2013. Metode Penelitian Pendidikan Pendekatan Kuantitatif, Kualitatif, dan R\&D. Bandung: Alfabeta.

Sugiyono. 2016. Metode Penelitian Kuantitatif, Kualitatif dan R\&D. Bandung: PT Alfabet. 